\title{
Pengaruh Metode Demonstrasi Berbasis Predict-Observe-Explain (POE) terhadap Kemampuan Metakognitif Siswa pada Materi Pemanasan Global
}

\section{Effect of Predict-Observe Explain-Based Demonstration Method (POE) on Student Metacognitive Abilities in Global Warming Material}

\author{
Yuliani $^{1}$, Mimin Nurjhani ${ }^{1 *}$, Suhara $^{1}$ \\ ${ }^{1}$ Program Studi Pendidikan Biologi, Departemen Pendidikan Biologi, FPMIPA, Universitas Pendidikan Indonesia \\ * Email Korespondensi: mimin_nk@yahoo.co.id
}

doi: http://dx.doi.org/10.29405/j.bes/3141-742159

Received: 22 September 2018 | Accepted: 26 Desember 2018 | Published: 27 Juni 2019

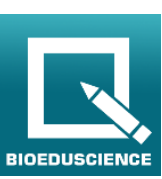

\begin{abstract}
Abstrak
Background: Kemampuan metakognitif merupakan kemampuan berpikir bagaimana untuk berpikir. Kemmapuan tersebut merupakan salah satu sasaran pembelajaran yang dituntut oleh kurikulum. Pada kenyataannya, di salah satu SMP Negeri di Kota Bandung, kemmapuan metakognitif siswa jarang dikembangkan padahal kemampuan metakognitif sangat penting dan dapat menunjang kemampuan akademik siswa. Metode Untuk itu, dalam penelitian ini dilaksanakan sebuah pembelajaran dengan menggunakan metode demonstrasi berbasis predict-observe-explain (POE) yang diharapkan dapat menunjang pencapaian kemampuan metakognitif siswa sesuai dengan tuntutan kurikulum. Siswa yang terlibat dalam penenlitian ini adalah satu kelas VII B yang dipilih secara acak. Pengukuran kemampuan metakognitif siswa dilakukan dengan menggunakan soal-soal jenis metakognitif yang dibuat oleh penulis sendiri dengan memperhatikan indikator. Pengukuran dilakukan sebelum dan setelah perlakuan. Hasil: Untuk mendukung data hasil penelitian, digunakan angket yang diadopsi dari Schraw \& Dennison (1994) yaitu angket Metacognitive Awareness Inventory (MAI) yang diberikan setelah perlakuan. Kesimpulan: Uji $\mathrm{T}$ menunjukan menunjukan bahwa terdapat perbedaan rata-rata secara signifikan sebelum dan setelah perlakuan menggunakan metode demonstrasi berbasis POE.
\end{abstract}

Kata kunci: Kemampuan metakognitif, Metode demonstrasi, POE, MAI

\section{Abstract}

Background: Metacognitive skills are the ability of how to think. The ability is one of the learning objectives required by the curriculum. In fact, in one of the Junior High School in Bandung, the ability metacognitive students rarely developed metacognitive abilities while very important and can support students' academic ability. Methods: Therefore, in this study conducted a study using a method-based demonstration is observed Predict-explain (POE) are expected to support the achievement of students' metacognitive skills according to the demands of the curriculum. Students involved in this research is a class VII B randomly selected. Measurement of metacognitive skills of students is done by using a kind of metacognitive problem created by the author himself to consider indicators. Measurements were performed before and after treatment. Results: To support the research data, we used a questionnaire that was adopted from Schraw and Dennison (1994), namely the metacognitive questionnaire Awareness Inventory (MAI), which was given after the treatment. Conclusions: T-test showed that there were differences in average significantly before and after treatment using a method-based demonstration POE.

Keywords: Metacognitive ability, Demonstration method, Predict-Observe - Explain (POE) MAI

Cara citasi: Yuliani, Nurjhani, M., \& Suhara. (2019). Pengaruh Metode Demonstrasi Berbasis Predict-Observe-Explain (POE) terhadap Kemampuan Metakognitif Siswa pada Materi Pemanasan Global. BIOEDUSCIENCE: Jurnal Pendidikan Biologi dan Sains, 03(01): 41-47. Doi: http://dx.doi.org/10.29405/j.bes/3141-742159

(C) 2019 Oleh authors. Lisensi Bioeduscience, Uhamka, Jakarta. Artikel ini bersifat open access yang didistribusikan di bawah syarat dan ketentuan Creative Commons Attribution (CC BY) license. (http://creativecommons.org/licenses/by/4.0/). 


\section{PENDAHULUAN}

Pada saat ini telah banyak ilmu pengetahun baru yang terus berkembang sepanjang masa. Proses belajar mengajar yang digunakan disekolah yang berpusat pada guru yang biasanya disebut dengan pengajaran tradisional. Tetapi seiring dengan perkembangan jaman pengajaran tradisional dianggap kurang dalam melatihkan kemampuan berpikir siswa. Pembelajaran mandiri atau pembelajaran yang berpusat pada siswa merupakakan pembelajaran yang dianjurkan oleh kurikulum di Indonesia saat ini.

Jika sistem pendidikan tidak mengajarkan siswa untuk berpikir, ketika siswa tumbuh menjadi dewasa, mereka akan lemah dalam berpikir dan tidak akan dapat berkompetensi dalam lingkungan masyarakat. Seperti yang diungkapkan dalam teori konstuktivisme yang menekankan penciptaan pengetahuan melalui kemampuan berpikir. Proses mencari dan menciptkan pengetahuan yang berasal dari diri sendiri tidak hanya untuk memenuhi otak kosong atau mengisi otak siswa dengan pengetahuan baru, tetapi juga mengembangkandan mengubah pengetahuan ang telah siswa miliki. Proses ini membuat siswa membangun dan menerima pengetahuan baru dan menata kembali struktur penegtahuan yang telah dimiliki sebelumnya dan hal tersebut akan membuat pembelajaran lebih bermakna.

Chikuni (Iline, 2013) juga menyatakan bahwa demonstrasi adalah suatu metode pembelajaran yang menunjukkan bagaimana sesuatu dilakukan dengan benar-benar melakukannya. Menurut (Iline, 2013) seorang siswa belajar lebih baik melalui meniru. Untuk mendukung hal ini, Hendrik (Iline, 2013) tahu bahwa anak-anak belajar dari yang dialaminya melalui apa yang mereka lihat. Oleh karena itu, demonstrasi harus dilakukan dengan benar agar siswa dapat mencontoh secara benar dalam melakukan sesuatu. Gwarinda (Iline, 2013) metode demonstrasi merupakan aplikasi teori dalam praktek. Soroka, Hoagland dan Mohale (Iline, 2013) mengemukakan bahwa metode demonstrasi harus digunakan untuk memberikan keterampilan. Itulah sebabnya metode ini sering disertakan dalam belajar mengajar mata pelajaran IPA.

Salah satu strategi pengajaran yang terstruktur secara konstruktivis yang memiliki relevansi langsung dengan penggunaan demonstrasi adalah pendekatan instruksional Predict-Observ-Explain (POE) (Chew Charles, 2005). Pendekatan ini menggabungkan unsurunsur dari kedua metode yang berpusat pada guru dan juga berpusat pada siswa. PredictObserv-Explain (POE) adalah strategi yang kuat untuk melakukan demonstrasi yang berbasis penyelidikan. Dalam POE ini guru menjadi salah satu bagian terpenting dalam memfasilitasi rekonstruksi pengetahuan siswa dan siswa terlibat dalam berpikir tingkat tinggi dan pemecahan masalah (Chew Charles, 2005). Dengan demikian metode demonstrasi akan lebih bermakna jika dimodifikasi dengan adanya POE dalam kegiatan pembelajarannya.

POE merupakan proses belajar mengajar berbasis konstruktivisme dalam proses pembelajarannya. Para siswa memiliki kesempatan untuk menunjukkan ide-ide mereka yang akurat dan ilmiah. Teknik ini juga mendukung kegiatan yang membuat siswa tahu bagaimana berpikir, apa yang harus dilakukan, dan cara untuk memecahkan masalah (Klangmanee. R. \& Sumranwanich., 2013). menyadari keuntungan dalam mengembangkan metakognisi dengan menggunakan POE tersebut.

Kemampuan metakognitif merupakan bagian dari proses pengaturan diri, kemampuan mengontrol proses berpikir diri sendiri. Pada tiap tahap (tahap orientasi, tahap organisasi, tahap eksekusi, dan tahap verifikasi) dalam menyelesaikan masalah siswa harus memonitor berpikirnya sekaligus membuat keputusankeputusan dalam melaksanakan tahapan yang dipilihnya itu agar masalah dapat terselesaikan 
dengan baik bahkan pada tahap akhir, siswa harus mempertanyakan kembali atas jawaban yang dibuatnya apakah jawabannya benarbenar telah sesuai dan apakah memungkinkan ada cara lain yang lebih efektif dalam menyelesaikan masalah yang diberikan itu.

\section{MATERI DAN METODE}

SMPN 12 Bandung dipilih sebagai lokasi penelitian dengan subjek penelitian kelas VII B. Sampel diambil secara acak (random sampling) meliputi 30 orang siswa. Random sampling dilakukan karena tidak ada kelas unggulan dan perbedaan kemampuan siswa dalam setiap kelas Dalam penelitian ini digunakan dua instrumen, yaitu tes kemampuan metakognitif dan angket Metacognitive Awareness Inventorry (MAI) yang di adopsi dari (Schraw, G. \& Dennison, 1994). Instrumen tes kemampuan metakognitif siswa dibuat oleh penulis berdasarkan indikator dengan soal berjenis metakognitif. Soal telah melalui tahapan judgment dan ujicoba sebelum diberikan kepada siswa. Hasil pengisian tes dianalisis dengan cara memberikan skor sesuai dengan jawaban siswa. Angket merupakan adopsi dari (Schraw, G. \& Dennison, 1994) berisi 52 pernyataan meliputi pernyataan yang menyatakan pengetahuan kognisi yang terdiri dari conditional knowledge, procedural knowledge dan declarative knowledge dan pernyataan mengenai regulasi kognisi yang terdiri dari planning, information management strategies, comprhension monitoring, dedugging strategies, dan evaluation. accountability, improving learning, problem solving, dan critical judgment. Hasil pengisian angket dianalisis dengan cara memberikan skor. Skor 1 untuk jawaban "Ya" dan skor 0 untuk jawaban "Tidak".

Kegiatan pembelajaran dilakukan dengan menggunakan metode demonstrasi berbasis Predict-Observe-Explain (POE) pada semester genap bulan April 2015. Kegiatan pembelajaran berlangsung selama 4 jam pelajaran yaitu $2 \mathrm{x}$ pertemuan dengan RPP yang telah dibuat. Sebelum dilakukan penelitian dilakukan kelas pembiasaan. Pembiasaan merupakan tahapan yang dilakukan sebelum pelaksanan penelitian. Pembiasaan dilakukan dengan tujuan untuk membiasakan siswa terhadap suatu model pembelajaran yang akan diterapkan yaitu model pembelajaran dengan menggunkan metode demonstrasi berbasis POE. Pembiasaan dilakukan sebanyak 2 kali pertemuan yaiu 2 x 40 menit. Topik yang diberikan dalam pembiasaan adalah topik mengenai pencemaran air dan pencemaran tanah. Pada kegiatan pembiasaan ini, siswa dibiasakan untuk membuat prediksi, melakukan observasi dan menuliskan eksplanasi.

Tes dilakukan $2 \mathrm{x}$ yaitu pretest dan postttest. Pretest dilakukan sebelum siswa diberikan perlakuan. Soal pada pretest sama dengan soal yang akan diberikan pada postttest. Waktu siswa untuk mengerjakan pretest adalah 30 menit. Setelah siswa menyelesaikan pretest kemudian perlakuan metode demonstrasi berbasis POE dilakukan.

Guru mendemonstrasikan media yang telah dibuat, kemudian siswa mengisi LKS yang diberikan. LKS berisi kegiatan dengan syntax POE yaitu siswa melakukan prediksi, siswa melakukan observasi dan siswa melakukan explanasi. Media yang digunakan adalah dumekologi yang menggambarkan keadaan kutub utara. Dalam media tersebut akan didemonstrasikan mengenai pemanasan global dan efek rumah kaca. Media terbuat dari kaca aquarium yang disekat untuk memberikan dua perlakuan.

Perlakuan yang diberikan adalah dengan memberikan $\mathrm{CO}_{2}$ kepada salah satu sisi dumekologi. $\mathrm{CO}_{2}$ tersebut dihasilkan dari campuran soda kue yang direaksikan dengan asam asetat glasial. $\mathrm{CO}_{2}$ yang diberikan merupakan penggambaran dari pemanasan global dan efek rumah kaca yang diakibatkan oleh memantulnya kembali panas ke bumi yang 
diakibatkan jumlah $\mathrm{CO}_{2}$ yang banyak terkumpul di atmosfer.

Pada media yang didemonstrasikan tersebut siswa dituntut untuk memprediksi hubungan meningkatnya gas $\mathrm{CO}_{2}$ dengan naiknya permukaan air laut, mengobservasi demonstrasi yang dilakukan deengan membandingkan tinggi permukaan air yang diakibatkan mencairnya es pada sisi dumekologi yang diberi $\mathrm{CO}_{2}$ dan tidak diberi $\mathrm{CO}_{2}$, selain itu siswa juga dituntut untuk melihat perubahan suhu pada kedua sisi dumekologi. Setelah pembelajaran selesai, dilakukan pengambilan data terakhir yaitu postttest dengan menggunakan soal yang telah dibuat. Waktu untuk menyelesaikan postttest sama dengan pretest yaitu 30 menit.

Pengolahan data dilakukan dengan menggunakan software SPSS. Pengaruh metode demonstrasi berbasis POE diketahui dengan membandingkan hasil rata-rata pretest dan posttest menggunakan uji t yang dilakukan dengan menggunakan software SPSS.

\section{HASIL}

Berdasarkan Tabel 1 data pada pretest berdistribusi normal dan rerata untuk pretest adalah 7,73 dari skor total 22 . Rerata tersebut cukup jauh dari skor ideal. Berdasarkan Tabel 1 terdapat nilai extrim sebesar 3 yang membuat rata-rata jauh dibawah skor ideal. Bila ditelusuri penyebabnya, kemampuan metakognitif awal pada siswa dapat dipengaruhi oleh berbagi faktor. Faktor utama penyebab siswa merasa kesulitan dalam mengisi pretest adalah pengetahuan awal siswa mengenai efek rumah kaca dan pemanasan global masih sangat minim. Faktor kedua yang menjadi penyebab kesulitan siswa dalam menjawab soal adalah ada beberapa soal yang menanyakan megenai percobaan efek rumah kaca. Faktor ketiga yang menjadi penyebab kesulitan siswa dalam menjawab soal pretest tersebut adalah soal yang diberikan merupakan soal dengan jenjang kemampuan tertingi yaitu jenjang metakognitif. Soal jenis metakognitif lebih banyak menanyakan startegi management informasi, palnning dan evaluating. Siswa sangat merasa kesulitan karena siswa sama sekali belum mendapat perlakuan untuk melatih kemampuan metakognitif.

Tabel 1. Rekapitulasi Hasil Uji Statistik Normalitas, Uji T Data Pretest dan Posttest Kemampuan Metakognitif Siswa

\begin{tabular}{ccc}
\hline Komponen & Pretest & Posttest \\
\hline $\mathrm{n}$ & 30 & 30 \\
Rata-rata & 7.73 & 15.17 \\
SD & 2.377 & 2.102 \\
Nilai Max & 15 & 20 \\
Nilai Min & 3 & 10 \\
\hline
\end{tabular}

Kebingungan siswa untuk menjawab pertanyaan-pertanyaan yang diajukan menandakan bahwa sebenarnya kebanyakan siswa belum terbiasa menghadapi pertanyaanpertanyaan yang membutuhkan pemikiran yang lebih kompleks. Kebiasaan berpikir seperti itu dapat terjadi karena sebelumnya siswa kurang mendapatkan kesempatan untuk melatih atau mengembangkan kemampuan berpikirnya. Hal itu terbukti dari soal-soal ulangan harian yang jarang memunculkan soal-soal jenis metakognitf. Maka tidak heran jika rerata kemampuan pretest sangat rendah.

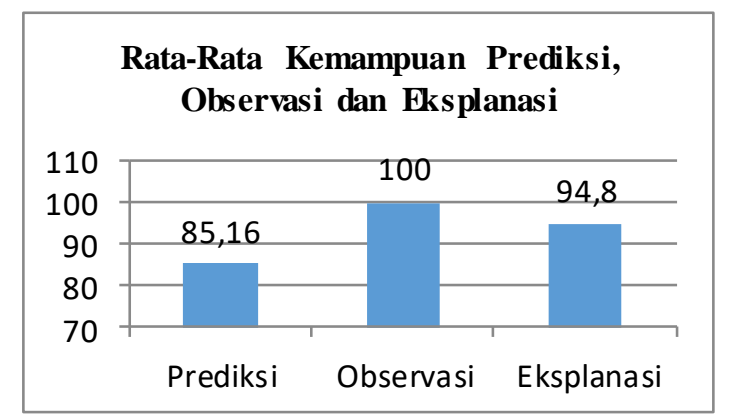

Gambar 1. Rata-rata kemampuan prediksi, observasi, dan eksplansi

Hasil uji statistik pada tabel 1 terhadap data posttest memperlihatkan bahwa rata-rata kemampuan metakognitif siswa setelah diberikan perlakuan lebih besar dari rata-rata kemmapuan metakognitif siswa sebelum dilakukan perlakuan. 


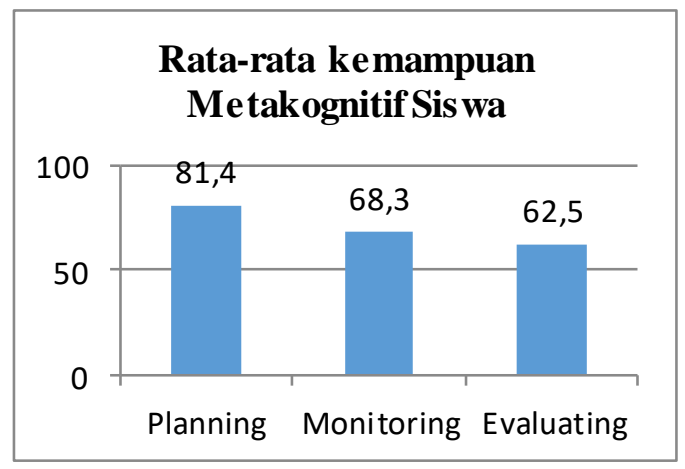

Gambar 2. Rata-rata kemampuan metakognitif siswa

Hasil analisis data posttest dengan menggunakan uji t, yaitu terdapat perbedaan rata-rata hasil pretest dan posttest. Rata-rata hasil posttest lebih baik bila dibandingkan dengan data hasil pretest. Hasil tersebut menunjukan bahwa terdapat pengaruh metode demonstrasi berbasis POE terhadap kemampuan metakognitif siswa.

Hasil tersebut didukung oleh hasil angket Metacognitive Awareness Inventory yang diberikan. Angket tersebut berisis 52 pernyataan pernyaaan yang dijawab dengan ya dan tidak. Pernyataan yang diberikan adalah pernyataan-pernyataan mengenai pengethuan kognisi dan egulasi kognisi. Hasil akhir untuk angket ini adalah berupa skor. Hasil penelitian menunjukan bahwa pada umumnya siswa untuk hasil regulasi kognisi berada pada persentase diatas $70 \%$, hal ini mengindikasikan bahwa kemampuan regulasi kognisi siswa pada umumnya sudah berada pada level baik. Hal tersebut didukung pula dari teori Flavel menunjukkan bahwa anak-anak yang masih kecil telah menyadari adanya pikiran, memiliki keterkaitan dengan dunia fisik, terpisah dari dunia fisik, dapat menggambarkan objek-objek dan peristiwa-peristiwa secara akurat atau tidak akurat, dan secara aktif menginterpretasi tentang realitas dan emosi yang dialami.

Anak-anak usia 3 tahun telah mampu memahami bahwa pikiran adalah peristiwa mental internal yang menyenangkan, yang referensial (merujuk pada peristiwa-peristiwa nyata atau khayalan), dan yang unik bagi manusia. Mereka juga dapat membedakan pikiran dengan pengetahuan.

Dari beberapa penelitian lain terungkap pula bahwa anak-anak yang masih kecil usia 22,5 tahun telah mengerti bahwa untuk menyembunyikan sebuah objek dari orang lain mereka harus menggunakan taktik penipuan, seperti berbohong atau menghilangkan jejak mereka sendiri. Hala et.al. dalam Desmita, (2006). Sementara Wellman dan Gelman (Desmita, 2006) menunjukkan bahwa pemahaman anak tentang pikiran manusia tumbuh secara ekstensif sejak tahun-tahun pertama kehidupannya. Kemudian pada usia 3 tahun anak menunjukkan suatu pemahaman bahwa kepercayaan-kepercayaan dan keinginan-keinginan internal dari seseorang berkaitan dengan tindakan-tindakan orang tersebut.

Berdasarkan hal ini, berarti kemampuan metakognitif telah berkembang sejak masa anak-anak awal dan terus berlanjut sampai usia sekolah dasar dan seterusnya mencapai bentuknya yang lebih mapan. Pada usia sekolah dasar seiring dengan tuntutan kemampuan kognitif yang harus dikuasai oleh anak/siswa, mereka dituntut pula untuk dapat menggunakan dan mengatur kognitif mereka.

Kemampuan metakognitf anak tidak muncul dengan sendirinya, tetapi memerlukan latihan sehingga menjadi kebiasaan. Perkembangan metakognitif dapat diupayakan melalui cara dimana anak dituntut untuk mengobserve tentang apa yang mereka ketahui dan kerjakan, dan untuk merefleksi tentang apa yang dia obeservasi. Pernyataan tersebut mengindikasikan bahwa observe dan refleksi dapat melatih kemampuan metakognitif dan hal tersebut sejalan dengan model POE yang dikembangkan dalam penelitian ini.

Untuk mengetahui hubungan antara kegiatan predict-observe-explain, maka dilakukan analisis terhadap hasil instrumen essay siswa dan dilakukan studi hubungan 
antara keduanya melalui data yang ditampilkan pada Gambar 1 dan Gambar 2. Pada hasil predict persentase kemampuan siswa dalam mempredict adalah $85,16 \%$ sedangkan persentase untuk kemampuan planning adalah $85,16 \%$. Berdasarkan data tersebut maka hasil kemampuan predict siswa memiliki kaitan erat dengan pada kemampuan planning. Jika siswa mampu melakukan predict dengan baik, maka siswa akan dapat merencanakan sesuatu dengan baik pula. Hal tersbeut di dukung oleh hasil angket yang menunjukan kemampuan planning siswa memiliki persentase $78 \%$.

Pada hasil observe persentase kemampuan siswa dalam mengobserve adalah $100 \%$, hasil tersebut didapatkan karena pada tahapan mengobserve ini siswa melihat demontrasi yang dilakukan guru, sehingga hasil yang mereka catat pada LKS adalah sama untuk seluruh siswa. Persentase untuk hasil monitoring siswa adalah 68,3\%. Hal tersebut terjadi karena pada saat observe tidak semua siswa melakukan pengamatan, banyak dari siswa yang hanya melihat hasil teman dan tidak mengobserve langsung pada media yang didemontrasikan guru. Hal tersebut menyebabkan hasil pada kemampuan monitoring siswa memiliki persentase yang rendah.

Berdasarkan data tersebut maka hasil kemampuan observe siswa berkaitan dengan kemapuan monitoring siswa. Jika siswa tidak melakukan observe dengan baik, maka hasil monitoring siswa pun menjadi kurang baik. Selain itu pada soal yang diberikan dibebani pula konsep-konsep pemanasan global sehingga siswa harus mengetahui pengetahuan yang sudah dimiliki untuk dapat menjawab soal.

Namun bila kita melihat hasil angket untuk kemampuan observe siswa dapat dikatakan baik yang mendapakan persentase $85,8 \%$. Hal tersebut menunjukan bahwa pengalaman siswa dalam mengobserve sebenarnya mereka dapatkan walaupun observe hanya dilakuakn dengan demonstrasi, namun dalam mengimpelemntasikan dan menghubungkan kedalam pengalaman baru siswa masih kurang.

Pada hasil explain persentase kemampuan siswa adalah 94,7 \% sedangkan persentase untuk kemampuan evaluation adalah $62,5 \%$. Berdasarkan data tersebut kemampuan explain siswa masuk kedalam kategori tinggi, namun pada kemampuan evaluating berada pada level rendah yaitu $62,5 \%$. Hal tersebut seakan menunjukan tidak ada kaitan antara kedua aspek tersebut. Namun bila dilihat dari aspek lain, bahwa soal evaluating yang diberikan kepada siswa memiliki beban konsep yang harus diketahui siswa, berbeda dengan explain yang ditampilkan di LKS, explain tersebut hanya menguraikan data yang siswa lihat saat observe. Beban konsep yang dibebankan inilah yang akhirnya membuat siswa mendapatkan persentase yang rendah. Hal tersebut didukung oleh hasil angket siswa pada pernyataanpernyataan yang mennaykan tentang evaluating dalam MAI, persentase hasil angket siswa dalam evaluating memiliki peresntase 91,6\%.

Kemampuan metakognitif dapat dikembangkan dengan menggunakan metode demonstrasi berbasis POE, namun dalam pembelajaran disekolah kemampuan metakognitif harus didukung pula oleh pengetahuan yang mereka miliki. Seperti halnya dalam penelitian ini, dalam mengerjakan soal posttest, setiap soal yang diberikan tidak ada siswa yang menjawab sempurna untuk setiap soal yang diberikan, setiap siswa pada umumnya telah bermetakognitif, namun yang menjadi kendala adalah pengetahuan yang mereka miliki kurang sehingga tidak dapat menjawab soal dengan sempurna. Hal tersebut bukan berarti bahwa siswa tidak bermetakognitif, siswa melakukan metakognitif dan telah memilki kemampuan metakognitif, hanya saja pengetahuan mereka dalam menjawab soal masih kurang. Hal tersebut mengindikasikan bahwa kemampuan 
metakognitif dalam pembelajaran disekolah dapat dikembangkan dan harus didukung pula oleh pengetahuan konsep yang diajarkan oleh guru. Dalam proses pembelajarannya pun diakhir pembelajaran diperlukan adanya penguatan, pada saat demonstrasi dilakukan konsepsi yang diberikan tidak merata, siswa yang mengamaati akan memiliki pengetahun yang lebih dari siswa yang tidak mengamatai, maka penguatan perlu dilakukan sehingga metakognitifnya menjadi lengkap.

\section{KESIMPULAN}

Berdasarkan hasil penelitian, posisi Berdasarkan hasil penelitian, dapat diketahui bahwa kemampuan metakognitif siswa awal dan setelah perlakuan berdistribusi normal. Hasil uji $t$ menunjukan bahwa terdapat perbedaan rata-rata kemampuan metakognitif siswa awal dan kemammpuan metakognitif setelah perlakuan, hal ini menunjukan bahwa terdapat pengaruh metode demosntrasi berbasis POE terhadap kemampuan metakognitif siswa.

Kegiatan belajar mengajar dengan menggunakan metode demonstrasi berbasis predict-observe-explain (POE) membuat siswa memiliki kemampuan untuk mengembangkan metakognisi dalam diri mereka. Ini berarti bahwa siswa memiliki kemampuan untuk merencanakan, memantau, dan mengevaluasi melalui proses pembelajaran diri dan berpikir. Siswa dapat mencapai tugas-tugas mereka sepenuhnya dengan menggunakan proses berbicara, berdiskusi dan berbagi pengetahuan dengan teman sekelas mereka.

\section{REFERENSI}

Chew Charles. (2005). Effect Of BiologyInfused Demonstations On Achievement and Attitudes In Junior College Physics, 7(2), 253-262.

Desmita. (2006). Psikologi Perkembangan. Bandung: PT. Remaja Rosdakarya.

Iline, C. S. (2013). Impacts of the
Demonstration Method in the Teaching and Learning of Hearing Impaired Children. IOSR Journal Of Humanities And Social Science, 12(5), 48-54.

Klangmanee. R. \& Sumranwanich. (2013). The Development of Grade 5 Thai Student's Metacognitive Strategies in Learning About Force and Preassure Through Predict Observe Explain (POE). Souutheast Asian Minister of Education Organisation, 8(3).

Schraw, G. \& Dennison, R. S. (1994). Assesing Metacognitive Awareness Contemporary Educational Psychology. Contemorary Educational Psychology, 19(4), Pages 460-475. https://doi.org/https://doi.org/10.1006/cep s.1994.1033 